Prepared in cooperation with the U.S. Environmental Protection Agency

\title{
Water-Balance Model of a Wetland on the Fort Berthold Reservation, North Dakota
}

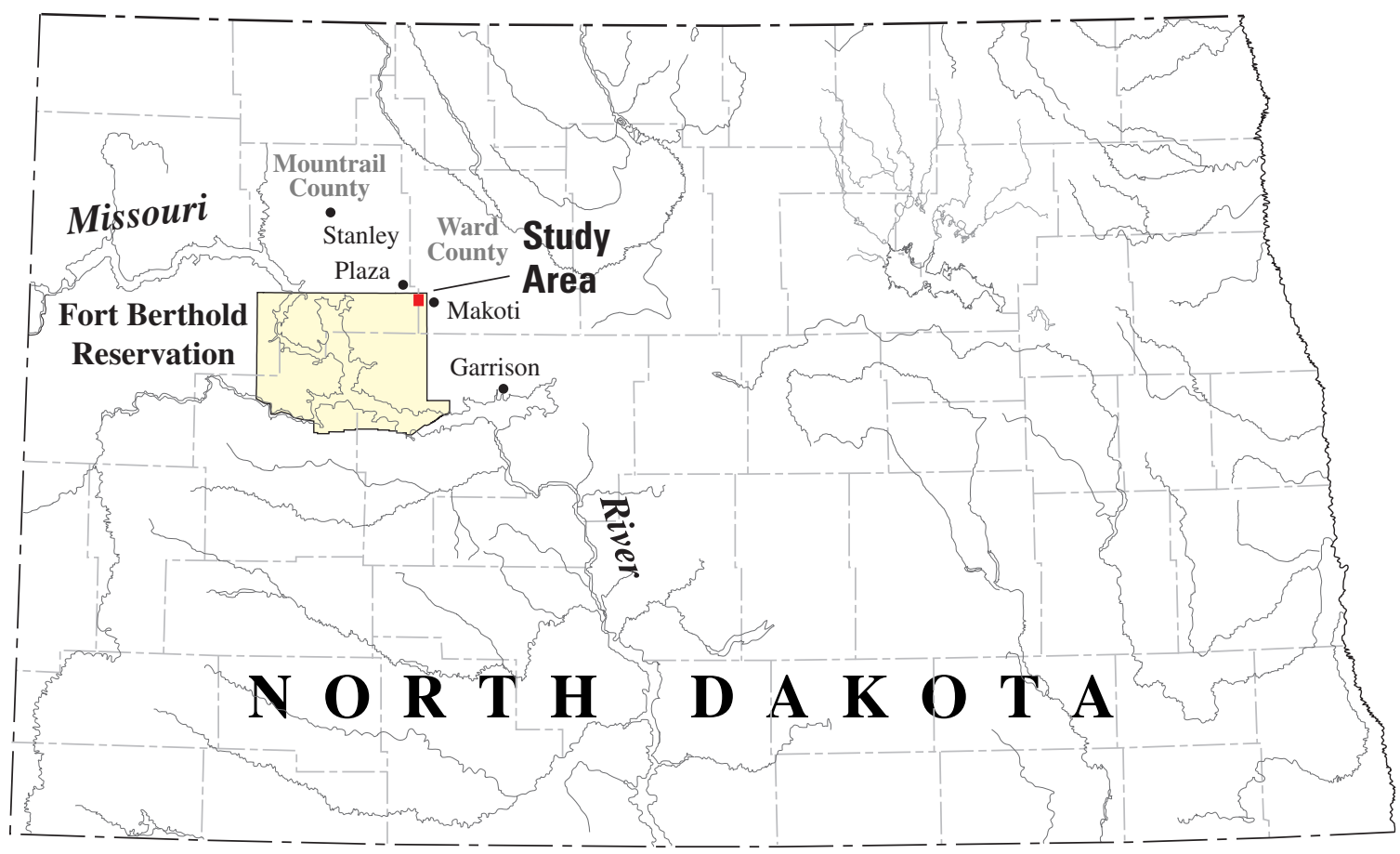

Scientific Investigations Report 2007-5034 


\section{Water-Balance Model of a Wetland on the Fort Berthold Reservation, North Dakota}

By Kevin C. Vining

Prepared in cooperation with the U.S. Environmental Protection Agency

Scientific Investigations Report 2007-5034 


\section{U.S. Department of the Interior DIRK KEMPTHORNE, Secretary}

\section{U.S. Geological Survey \\ Mark D. Myers, Director}

U.S. Geological Survey, Reston, Virginia: 2007

For product and ordering information:

World Wide Web: http://www.usgs.gov/pubprod

Telephone: 1-888-ASK-USGS

For more information on the USGS--the Federal source for science about the Earth, its natural and living resources, natural hazards, and the environment:

World Wide Web: http://www.usgs.gov

Telephone: 1-888-ASK-USGS

Any use of trade, product, or firm names is for descriptive purposes only and does not imply endorsement by the U.S. Government.

Although this report is in the public domain, permission must be secured from the individual copyright owners to reproduce any copyrighted materials contained within this report.

Suggested citation:

Vining, K.C., 2007, Water-balance model of a wetland on the Fort Berthold Reservation, North Dakota: U.S. Geological Survey Scientific Investigations Report 2007-5034, 15 p. 


\section{Contents}

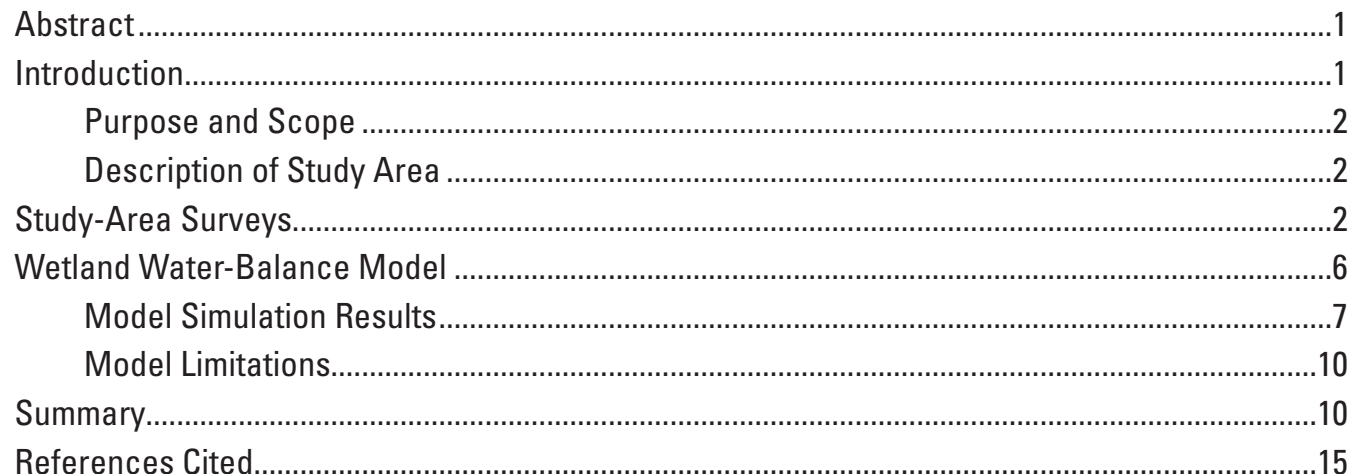

\section{Figures}

1. Maps showning locations of study area and study wetland on the Fort Berthold Reservation, North Dakota.

2-7. Graphs showing:

2. Locations of land-surface contours and survey points in study wetland. .4

3. Least-squares regression of wetland water-surface area $(Y)$ and wetland water-surface elevation $(X)$

4. Simulated daily wetland water volumes and daily precipitation using the historical climate data set for May and June 2005 in the wetland water-balance model

5. Simulated daily wetland water volumes and daily precipitation using the historical-enhanced climate data set for May and June 2005 in the wetland water-balance model.

6. Simulated daily wetland water volumes and daily precipitation using the extreme summer climate data set for May and June 2005 in the wetland water-balance model

7. Simulated daily wetland water volumes and daily precipitation using the extreme winter climate data set for an arbitrary March and April in the wetland water-balance model.

\section{Tables}

1. Daily precipitation and evapotranspiration data and selected simulation results from the historical climate data set for May and June 2005

2. Daily precipitation and evapotranspiration data and selected simulation results from the historical-enhanced climate data set for May and June 2005

3. Daily precipitation and evapotranspiration data and selected simulation results from the extreme summer climate data set for May and June 2005.

4. Daily precipitation and evapotranspiration data and selected simulation results from the extreme winter climate data set for an arbitrary March and April. 


\section{Conversion Factors}

Inch/Pound to SI

\begin{tabular}{lcl}
\hline Multiply & By & To obtain \\
\hline inch (in.) & Length & \\
inch (in.) & 2.54 & centimeter $(\mathrm{cm})$ \\
foot (ft) & 25.4 & millimeter $(\mathrm{mm})$ \\
mile (mi) & 0.3048 & meter $(\mathrm{m})$ \\
\hline & 1.609 & kilometer $(\mathrm{km})$ \\
\hline acre & Area & \\
acre & 4,047 & square meter $\left(\mathrm{m}^{2}\right)$ \\
acre & 0.4047 & hectare $($ ha) \\
acre & 0.4047 & square hectometer $\left(\mathrm{hm}^{2}\right)$ \\
& 0.004047 & square kilometer $\left(\mathrm{km}^{2}\right)$ \\
\hline acre-foot (acre-ft) & Volume & \\
acre-foot (acre-ft) & 1,233 & cubic meter $\left(\mathrm{m}^{3}\right)$ \\
\hline & 0.001233 & cubic hectometer $\left(\mathrm{hm}^{3}\right)$ \\
\hline acre-foot per day (acre-ft/d) & Flow rate & \\
inch per hour (in/h) & 0.01427 & cubic meter per second $\left(\mathrm{m}^{3} / \mathrm{s}\right)$ \\
\hline
\end{tabular}

Temperature in degrees Fahrenheit $\left({ }^{\circ} \mathrm{F}\right)$ may be converted to degrees Celsius $\left({ }^{\circ} \mathrm{C}\right)$ as follows:

$$
{ }^{\circ} \mathrm{C}=\left({ }^{\circ} \mathrm{F}-32\right) / 1.8
$$

Vertical coordinate information is referenced to the National Geodetic Vertical Datum of 1929 (NGVD 29).

Horizontal coordinate information is referenced to the North American Datum of 1983 (NAD 83).

Elevation, as used in this report, refers to distance above the vertical datum. 


\title{
Water-Balance Model of a Wetland on the Fort Berthold Reservation, North Dakota
}

\author{
By Kevin C. Vining
}

\section{Abstract}

A numerical water-balance model was developed to simulate the responses of a wetland on the Fort Berthold Reservation, North Dakota, to historical and possible extreme hydrological inputs and to changes in hydrological inputs that might occur if a proposed refinery is built on the reservation. Results from model simulations indicated that the study wetland would likely contain water during most historical and extreme-precipitation events with the addition of maximum potential discharges of 0.6 acre-foot per day from proposed refinery holding ponds. Extended periods with little precipitation and above-normal temperatures may result in the wetland becoming nearly dry, especially if potential holding-pond discharges are near zero. Daily simulations based on the historical-enhanced climate data set for May and June 2005, which included holding-pond discharges of 0.6 acre-foot per day, indicated that the study-wetland maximum simulated water volume was about 16.2 acre-feet and the maximum simulated water level was about 1.2 feet at the outlet culvert. Daily simulations based on the extreme summer data set, created to represent an extreme event with excessive June precipitation and holding-pond discharges of 0.6 acre-foot per day, indicated that the study-wetland maximum simulated water volume was about 38.6 acre-feet and the maximum simulated water level was about 2.6 feet at the outlet culvert. A simulation performed using the extreme winter climate data set and an outlet culvert blocked with snow and ice resulted in the greatest simulated wetland water volume of about 132 acre-feet and the greatest simulated water level, which would have been about 6.2 feet at the outlet culvert, but water was not likely to overflow an adjacent highway.

\section{Introduction}

The Mandan, Hidatsa, and Arikara Nation on the Fort Berthold Reservation, North Dakota, has proposed building a clean-fuels refinery on the reservation to promote economic development (U.S. Environmental Protection Agency, 2003). The proposed refinery, which would produce gasoline and diesel fuel, likely would use ground water and perhaps some surface water in the refining process. Treated process water and precipitation-generated runoff from the proposed refinery would be stored in proposed surface holding ponds and then would be discharged from the ponds into a wetland adjacent to the proposed refinery (Horace Pipe, Chief Geologist, HD Geological, oral commun., 2006). Preliminary refinery designs indicate water from the holding ponds may be discharged into the wetland at the rate of about 0.09 to 0.6 acre-foot per day (Gwen Jacobs, U.S. Environmental Protection Agency, written commun., 2006). Designs for the proposed refinery contain various alternatives that may affect the amounts of water entering the holding ponds and that may affect the maximum discharge from the ponds into the wetland.

The Bureau of Indian Affairs, with the cooperation of the Mandan, Hidatsa, and Arikara Nation and with assistance from the U.S. Environmental Protection Agency, is preparing an environmental impact statement concerning the effects of the proposed refinery on a wetland and the surrounding lands on the reservation. Environmental concerns include wildlife habitat, air quality, ground-water quantity and quality, and surface-water quantity and quality. Information on the effects that natural and human-induced variability could have on runoff volumes generated and stored in the wetland and on water flows from the wetland and the surrounding lands could be provided by using water-balance modeling. The water balance for a wetland can be stated as follows: the change in wetland water volume equals the water volume entering the wetland minus the water volume leaving the wetland (Woolhiser and Brakensiek, 1982). Variability in precipitation, wetland physical condition, evaporation, ground-water interaction, drainage, and the amount and condition of the area contributing to runoff likely will have an effect on the storage and movement of water in a wetland. To assist in the gathering of information for the environmental impact statement, the U.S. Geological Survey, in cooperation with the U.S. Environmental Protection Agency, developed a numerical water-balance model to simulate the responses of a wetland on the Fort Berthold Reservation to historical and possible extreme hydrological inputs and to changes in hydrological inputs that might occur if the proposed refinery is built. The main objective of the study was to evaluate water volumes in and flows from the wetland that may result from possible extreme precipitation events during summer and winter in conjunction with maximum potential 
discharges of 0.6 acre-foot per day from proposed refinery holding ponds.

\section{Purpose and Scope}

The purpose of this report is to describe the collection and analysis of survey data obtained in May 2006 from a study area on the Fort Berthold Reservation and to present the results of numerical water-balance model simulations of a study wetland. Data for the water-balance model and simulations performed with the model were for May and June 2005, a period that represented a climatologically wet period for the study wetland. A simulation of the study wetland in which altered May and June 2005 climate data were used to simulate an arbitrary extreme winter March and April was performed. Model simulations included the effects of historical climate, artificially enhanced climate, and potential discharges from proposed refinery holding ponds on water volumes and waterlevel elevations of and flows from the study wetland. Historical water-level and flow data from the study wetland were not available for model calibration and validation, so simulation results are considered preliminary.

\section{Description of Study Area}

The study area, which includes the study wetland, is located northwest of Makoti on the Fort Berthold Reservation, North Dakota (fig. 1). The extents of the wetlands and lakes were approximated using aerial photography. As determined from topographic maps, the study wetland has an area of about 11.7 acres and the surrounding land that could contribute runoff to the wetland has an area of about 218 acres (Gwen Jacobs, U.S. Environmental Protection Agency, written commun., 2006). The study wetland likely receives most of its inflow water from spring snowmelt and rainfall. The 1971-2000 average annual temperature and precipitation near the study wetland were about 39.3 degrees Fahrenheit and 17.88 inches, respectively (National Climatic Data Center, 2002). The land surrounding the study wetland is mostly agricultural and is mostly loamy soils that developed on glacial till and that have good drainage, permeabilities of 0.2 to 2 inches per hour, and 0- to 4-percent slopes; the study wetland exists on silty clay soils that developed on glacial till and that have poor drainage, permeabilities of 0.06 to 2 inches per hour, and almost no slope (Howey and others, 1974). A previous investigation indicates ground-water interaction with the wetland was likely minimal for any wetland water-level elevation (GeoTrans, Inc., oral commun., 2006). The wetland contained some water in May 2006; however, unrecorded observations made by members of the Mandan, Hidatsa, and Arikara Nation indicate the wetland possibly could become dry during extended droughts.
Water can drain from the study wetland northward into East Fork Shell Creek through a 2.5-foot diameter outlet culvert under Highway 23 (fig. 1). Observations of flow through the culvert that would assist in the classification of culvert flow are not available. Therefore, on the basis of measurements, assumptions, channel conditions, and culvert-flow calculations, maximum flow through the outlet culvert was determined to be about 25 acre-feet per day (Bodhaine, 1968). A constructed ditch connects the study wetland through south culvert to a second larger wetland about 0.5 mile to the southeast of the study wetland, and the ditch continues through west culvert to a small lake about 0.5 mile to the west of the second larger wetland (fig. 1). Alterations to the ditch connecting the study wetland and the second larger wetland to the southeast may occur depending on final refinery design. In addition, refinery designs have indicated the refinery holding ponds may be located adjacent to the constructed ditch directly south of the study wetland.

\section{Study-Area Surveys}

The study wetland and nearby south and west culverts within the study area were surveyed in May 2006 to determine the relations of land-surface elevations to potential wetland water-surface areas and water volumes. All surveys were referenced to a nearby benchmark established in March 2005 at an elevation of 2,079.63 feet (GeoTrans, Inc., written commun., 2006).

Data points obtained during the survey of the study wetland, including the wetland wetted edge, were plotted and land-surface contours were drawn at 0.5-foot intervals (fig. 2). Because of possible alterations to the constructed ditch during final refinery design, the extent of the study wetland and the land-surface contours drawn at the southeast edge of the study wetland were approximated. The lowest surveyed point in the study wetland had an elevation of 2,064.45 feet. An assumption was made that the lowest point in the wetland likely was not surveyed. Therefore, the lowest point in the wetland was assigned an elevation of 2,064.40 feet. Potential water-surface areas within each contour were determined by using a planimeter. Incremental water volumes between each pair of contours were determined by multiplying the average area of the two contours by the incremental elevation change. Incremental volumes were summed to obtain total potential water volumes. Errors in the calculation of potential water volumes may have occurred as a result of errors in the elevations and locations of surveyed points, errors during contouring, and errors in the determination of potential water-surface areas. However, most of the surveying and calculation errors likely would be less than 3 percent. Potential contour-interval errors in U.S. Geological Survey topographic products typically are one-half of the contour interval, or 0.25 foot for this study. 


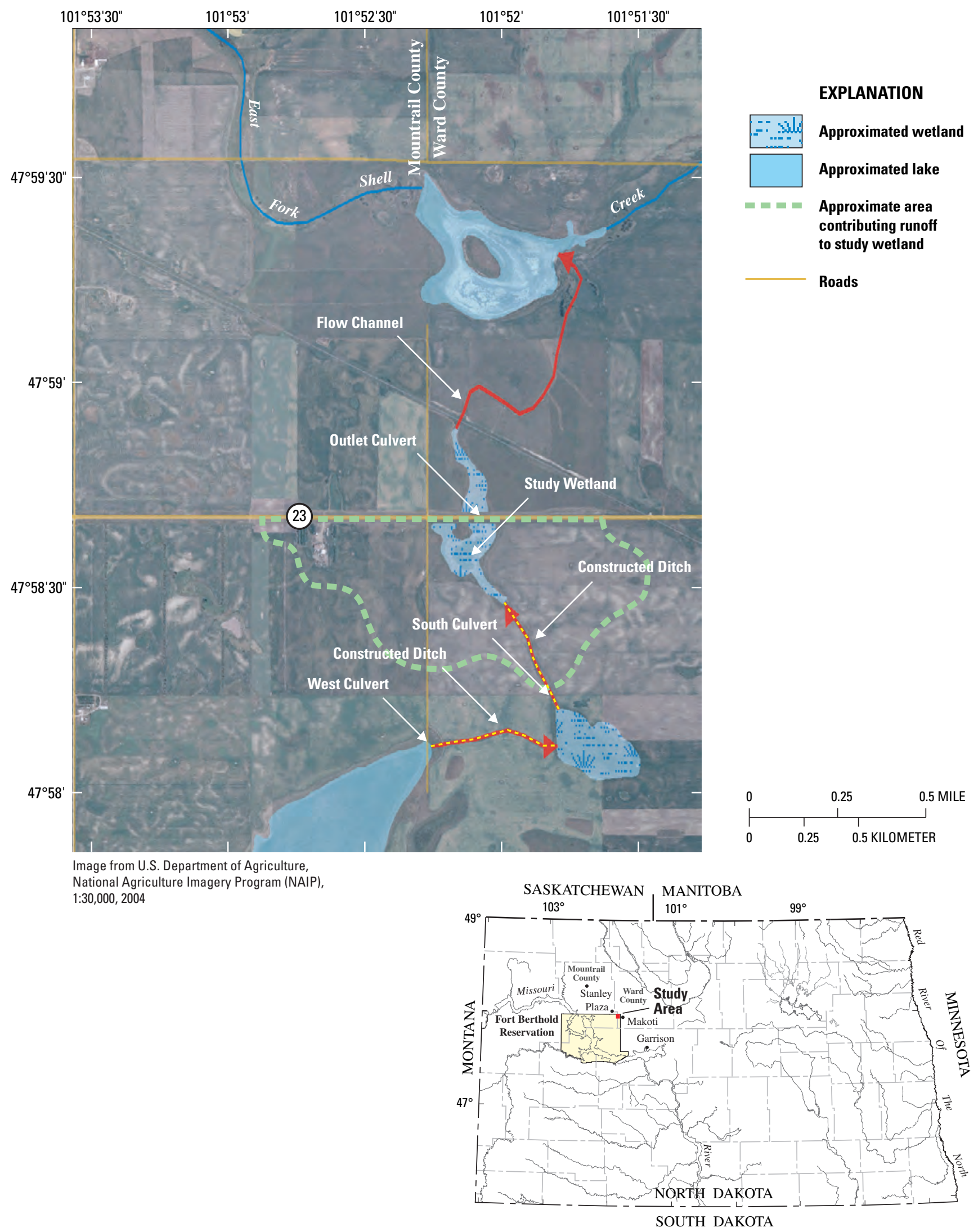

Figure 1. Locations of study area and study wetland on the Fort Berthold Reservation, North Dakota. 


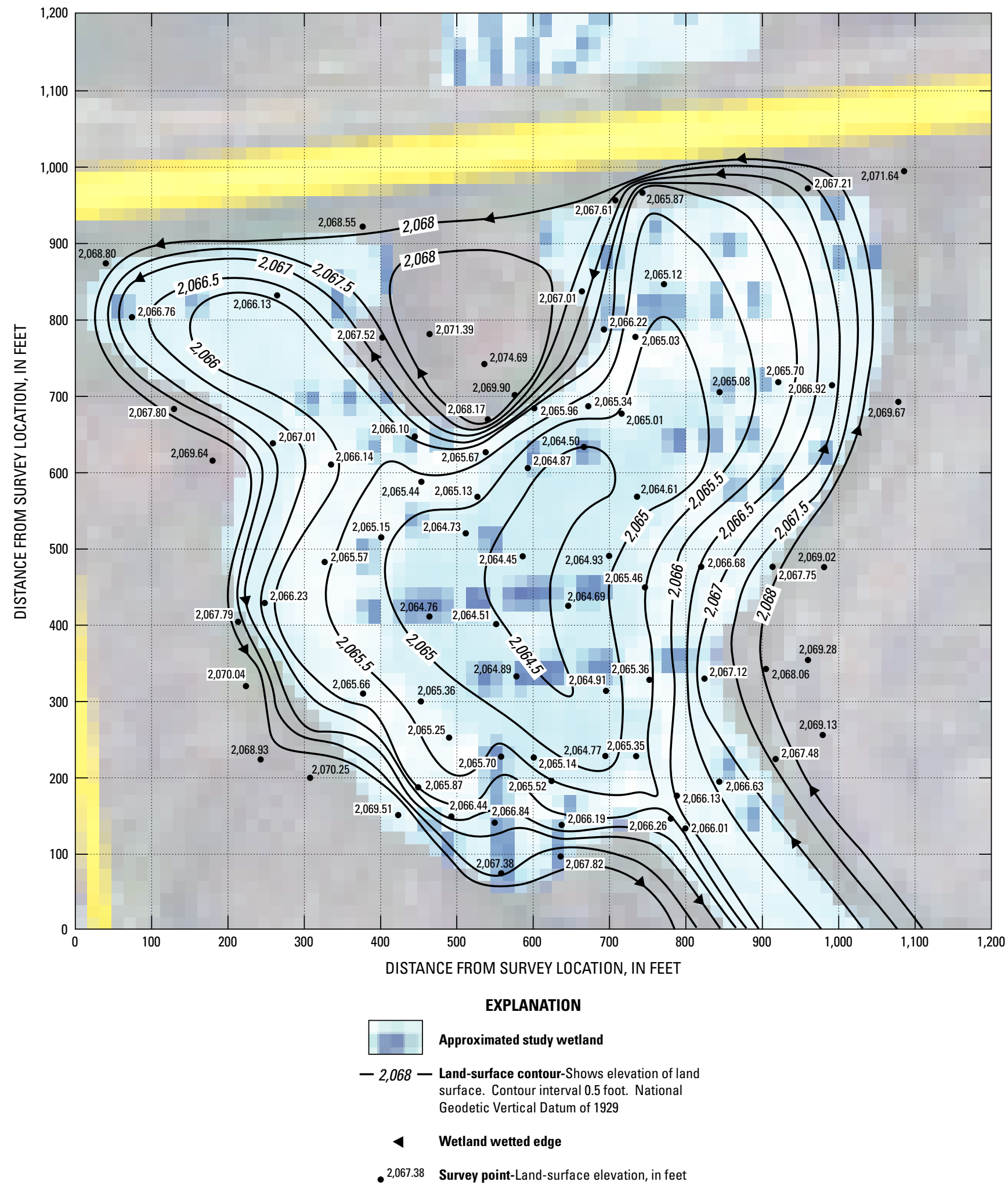

Figure 2. Locations of land-surface contours and survey points in study wetland. 
A plot of wetland water-surface areas, in acres, and wetland water-surface elevations, in feet, indicated a linear relation (fig. 3). A least-squares regression between the two variables resulted in equation 1 :

$$
Y=4.51536 X-9,321.472 \text {, }
$$

where

$Y \quad$ is wetland water-surface area, in acres; and $X$ is water-surface elevation, in feet.

The correlation coefficient of the regression was 0.999 . Wetland water volume could be calculated by using equation 1 and multiplying wetland water-surface area by one-half the difference between the water-surface elevation and 2,064.40 feet. Using equation 1, the study wetland water-surface area at the outlet culvert entrance elevation (2,065.87 feet) is about 6.7 acres and the wetland water volume at the outlet culvert entrance elevation is about 4.9 acre-feet. Because few points were surveyed above elevations of 2,068 feet, the relation between wetland water volume and water-surface elevation was extrapolated for water-surface elevations greater than 2,068 feet.

The outlet culvert entrance elevation of 2,065.87 feet was determined by a survey of the study wetland and was confirmed by the North Dakota Department of Transportation, which indicated the elevation of the entrance was 2,065.9 feet (Clifford Scott, North Dakota Department of Transportation, oral commun., 2006). Surveys of south culvert and west culvert in the constructed ditch indicated the entrances were at elevations of 2,066.14 and 2,065.51 feet, respectively. Although no surveys were made of elevations within the constructed ditch, culvert entrance elevations indicated water possibly could flow within the constructed ditch if water-level elevations reached 2,066.14 feet. However, possible water flow in the constructed ditch was not considered for this study because final refinery designs may include alterations to the ditch.

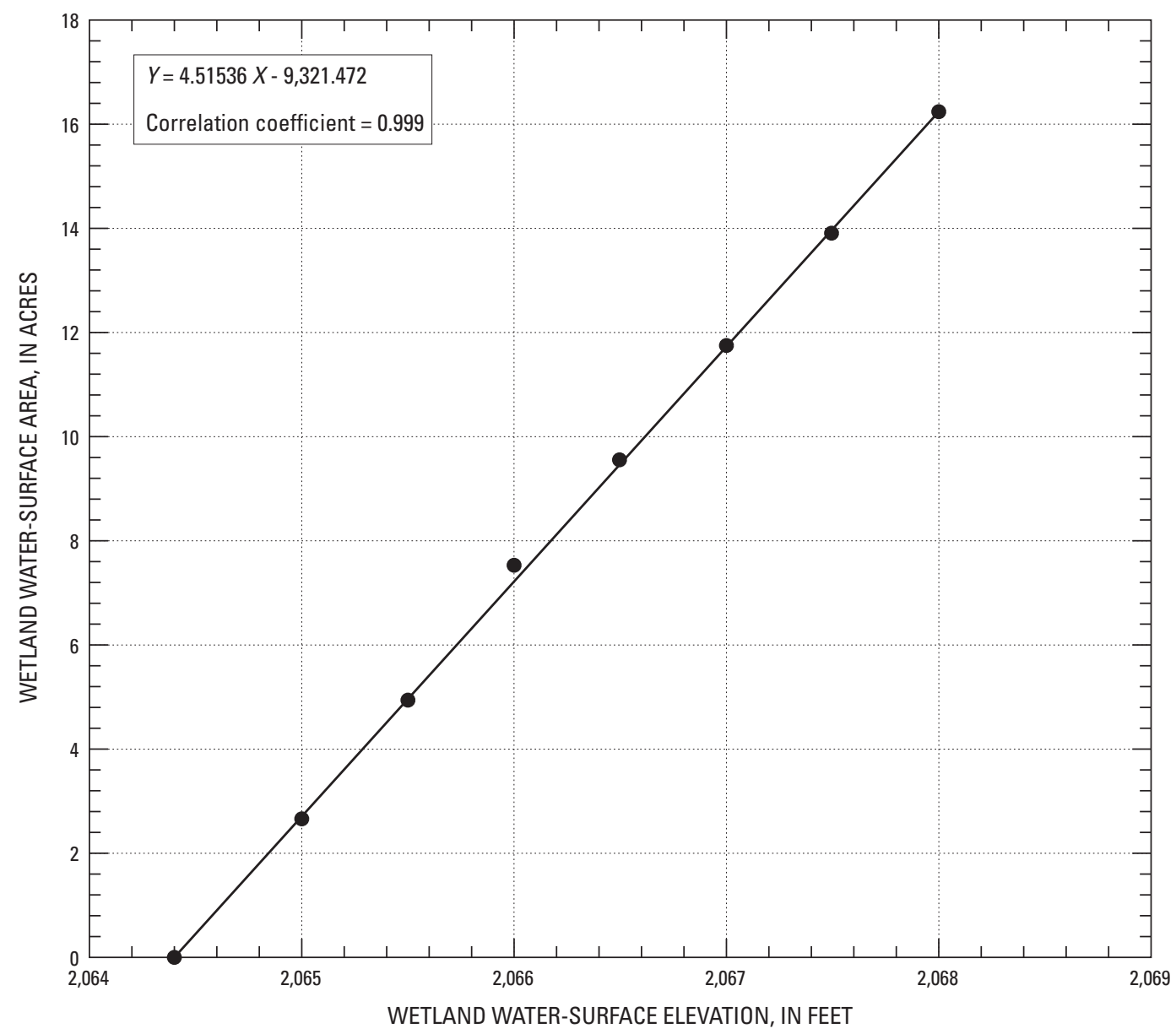

Figure 3. Least-squares regression of wetland water-surface area $(Y)$ and wetland water-surface elevation $(X)$. 


\section{Wetland Water-Balance Model}

A numerical water-balance model of the study wetland on the reservation was developed using Microsoft Excel ${ }^{\circledR}$ to determine daily wetland water volumes associated with historical climate events and with possible extreme summer and winter precipitation events that could occur in conjunction with maximum potential discharges of 0.6 acre-foot per day from proposed refinery holding ponds. The model calculated the daily change in wetland water volume that resulted from the difference between the daily volumes of water that entered the wetland and the daily volumes of water that left the wetland. Volumes of water that entered the wetland included precipitation on the wetland, precipitation-generated runoff from surrounding lands, and discharges from the proposed refinery holding ponds. Volumes of water that left the wetland included evapotranspiration and culvert discharge. Groundwater interaction with the wetland was likely minimal for any wetland water-level elevation (GeoTrans, Inc., oral commun., 2006).

A historical climate data set for May and June 2005 was created with data obtained from a North Dakota Agricultural Weather Network station south of Plaza, North Dakota (North Dakota State University, 2006). The data included measured daily precipitation and daily potential evapotranspiration calculated by using the Penman formulation (Penman, 1948). During May and June 2005, about 13.09 inches of rain was recorded at the weather station. That period likely represented a climatologically wet 2-month period for the study wetland. During June 2005, about 10.29 inches of rain was recorded at the weather station. By comparison, maximum June precipitation during 1948 through 2005 for climate stations at Garrison and Stanley, North Dakota, was 11.86 and 10.02 inches, respectively (High Plains Regional Climate Center, 2006). The simulation performed using the historical climate data set will be referred to as the historical simulation. For another simulation, which will be referred to as the historical-enhanced simulation, a maximum potential holdingpond discharge of 0.6 acre-foot per day was included in the historical climate data set.

Another climate data set was created to represent possible extreme summer climate conditions by artificially enhancing the June 22 through 25, 2005, daily precipitation values of zero in the historical climate data set with the arbitrary values of $0.5 \mathrm{inch}, 1 \mathrm{inch}, 4.5 \mathrm{inches}$, and $0.5 \mathrm{inch}$, respectively. The artificially enhanced maximum daily precipitation of 4.5 inches and maximum 4-day total of 6.99 inches for the study area compared well to historical climate data for 1948 through 2005 that showed Garrison and Stanley maximum daily precipitation values were 4.35 and 3.25 inches, respectively, and maximum 4-day precipitation totals were 5.48 and 5.41 inches, respectively (High Plains Regional Climate Center, 2006). Daily evapotranspiration values for June 22 through 25 were assigned arbitrary values that were 17 percent, 15 percent, 37 percent, and 32 percent less, respectively, in the extreme summer climate data set than in the historical data set to account for possible increased cloudiness and higher humidity during those days with artificially enhanced precipitation. A maximum potential holding-pond discharge of 0.6 acre-foot per day was included in the data set. The simulation performed using the extreme summer climate data set will be referred to as the extreme summer simulation.

A final data set was created to represent extreme winter climate conditions for an arbitrary March and April. This data set had the same artificially enhanced precipitation data as the extreme summer climate data set but had daily evapotranspiration values arbitrarily set to 0.05 inch per day to simulate reduced evaporation and possible sublimation during winter conditions. The wetland outlet culvert was assumed to be completely blocked with ice and snow. A maximum potential holding-pond discharge of 0.6 acre-foot per day was included in the data set. The simulation performed using the extreme winter climate data set will be referred to as the extreme winter simulation.

The daily water-balance model of the study wetland was developed using information from the study-area surveys; discussions with Mandan, Hidatsa, and Arikara Nation and U.S. Environmental Protection Agency personnel; and observations of physical conditions at the study area. The model was developed with the following assumptions: (1) groundwater interaction with the study wetland was zero, (2) initial area contributing to runoff to the study wetland was 16 acres, which consisted of the study wetland area plus the wetland wetted-edge area to an elevation of 2,068 feet, (3) one-third of the wetland water volume above the outlet culvert entrance elevation flowed from the study wetland each day, (4) water flowed from the study wetland in the downstream (north) direction only, and (5) evapotranspiration from the calculated wetland open-water area occurred at the potential (Penman) rate.

Another assumption used in the water-balance model was that runoff from the land surrounding the study wetland was generated when antecedent 2-day total precipitation exceeded a threshold of 0.06 foot $(0.72 \mathrm{inch})$. This assumption, intended to incorporate antecedent soil moisture into the water-balance model, was based on the soil permeabilities of the surrounding lands and on rainfall-runoff studies. One study showed that runoff occurred from dry soil with herbaceous vegetation after 9 minutes during a 0.1 -inch-perminute simulated rainfall that lasted for 15 minutes and from wet soil with herbaceous vegetation after 10 minutes during a 0.03-inch-per-minute simulated rainfall that lasted for 90 minutes (Sorenson, 2004). Another study showed that runoff occurred from a hillside (4.5-percent slope) covered with sparse grass and trees after 5 minutes during a 2.36-inchesper-hour simulated rainfall whether the soil was dry or slightly wet (Johansen and others, 2001).

The area contributing to runoff to the study wetland was estimated by multiplying the assumed initial contributing area (16 acres) by the ratio of the antecedent 2-day precipitation to 
the assumed threshold for generating runoff ( 0.06 foot). The area contributing to runoff to the study wetland was calculated using equation 2 :

$$
A=A i+A i((P-0.06) / 0.06),
$$

where

$A$ is the calculated contributing area, in acres;

$A i$ is the assumed initial contributing area, in acres; and

$P \quad$ is the antecedent 2-day precipitation, in feet.

Daily runoff volumes contributed to the study wetland were calculated as the product of daily precipitation and calculated contributing area. The approach used in equation 2 was intended, as was the approach for the runoff-generation precipitation threshold, to incorporate antecedent soil moisture into the water-balance model. Equation 2 follows an equation used to estimate contributing area in which the difference between the maximum and minimum contributing area was multiplied by the ratio of available soil moisture to maximum soil moisture (Leavesley and others, 1983).

\section{Model Simulation Results}

The wetland water-balance model was run on a daily time step during simulations using the historical climate data set, the historical-enhanced climate data set, the extreme summer climate data set, and the extreme winter climate data set. Initial water volume of the study wetland during all simulations was set at 4.9 acre-feet, which was about the maximum wetland water volume without drainage through the outlet culvert. Simulation results for June 15 through 30, 2005, were used for comparison because of the data differences among the historical, historical-enhanced, and extreme summer climate data sets during that period.

The historical simulation indicated the maximum wetland water volume was about 15.0 acre-feet; the maximum occurred on June 29 as a result of a 2.72-inch rainfall (table 1; fig. 4). The simulated water-surface elevation in the study wetland on June 29 was about 2,066.96 feet, or, water would have been about 1.1 feet deep at the outlet culvert. The maximum simulated area contributing to runoff on June 29 was about 64.4 acres, and the maximum simulated culvert flow was about 5.1 acre-feet per day. Simulated culvert flow was zero on several days during the simulation.

Table 1. Daily precipitation and evapotranspiration data and selected simulation results from the historical climate data set for May and June 2005.

\begin{tabular}{cccccccc}
\hline $\begin{array}{c}\text { Date } \\
\text { (month/day/vear) }\end{array}$ & $\begin{array}{c}\text { Precipitation } \\
\text { (inches) }\end{array}$ & $\begin{array}{c}\text { Evapotranspiration } \\
\text { (inches) }\end{array}$ & $\begin{array}{c}\text { Simulated area } \\
\text { contributing to } \\
\text { runoff } \\
\text { (acres) }\end{array}$ & $\begin{array}{c}\text { Simulated runoff } \\
\text { water volume } \\
\text { (acre-feet } \\
\text { per day) }\end{array}$ & $\begin{array}{c}\text { Simulated } \\
\text { culvert flow } \\
\text { (acre-feet } \\
\text { per day) }\end{array}$ & $\begin{array}{c}\text { Simulated } \\
\text { wetland } \\
\text { water volume } \\
\text { (acre-feet) }\end{array}$ & $\begin{array}{c}\text { Simulated } \\
\text { wetland } \\
\text { water-surface } \\
\text { elevation } \\
\text { (feet) }\end{array}$ \\
\hline $6 / 15 / 2005$ & 0 & 0.25 & 16.0 & 0 & 0 & 4.76 & $2,065.82$ \\
$6 / 16 / 2005$ & 0 & .25 & 16.0 & 0 & 0 & 4.62 & $2,065.80$ \\
$6 / 17 / 2005$ & 0 & .33 & 16.0 & 0 & 0 & 4.45 & $2,065.77$ \\
$6 / 18 / 2005$ & 0 & .31 & 16.0 & 0 & 0 & 4.29 & $2,065.74$ \\
$6 / 19 / 2005$ & .33 & .28 & 16.0 & .44 & 0 & 4.59 & $2,065.79$ \\
$6 / 20 / 2005$ & .03 & .26 & 16.0 & .04 & 0 & 4.49 & $2,065.78$ \\
$6 / 21 / 2005$ & 1.16 & .29 & 26.4 & 2.56 & .66 & 6.23 & $2,066.03$ \\
$6 / 22 / 2005$ & 0 & .29 & 25.8 & 0 & .38 & 5.67 & $2,065.95$ \\
$6 / 23 / 2005$ & 0 & .27 & 16.0 & 0 & .20 & 5.31 & $2,065.90$ \\
$6 / 24 / 2005$ & 0 & .27 & 16.0 & 0 & .09 & 5.07 & $2,065.87$ \\
$6 / 25 / 2005$ & 0 & .31 & 16.0 & 0 & 0 & 4.90 & $2,065.84$ \\
$6 / 26 / 2005$ & .99 & .12 & 22.0 & 1.82 & .58 & 6.07 & $2,066.01$ \\
$6 / 27 / 2005$ & .06 & .16 & 23.3 & .12 & .40 & 5.69 & $2,065.96$ \\
$6 / 28 / 2005$ & .18 & .15 & 16.0 & .24 & .31 & 5.53 & $2,065.93$ \\
$6 / 29 / 2005$ & 2.72 & .08 & 64.4 & 14.6 & 5.06 & 15.0 & $2,066.96$ \\
$6 / 30 / 2005$ & .06 & .20 & 61.8 & .31 & 3.41 & 11.7 & $2,066.66$ \\
\hline
\end{tabular}




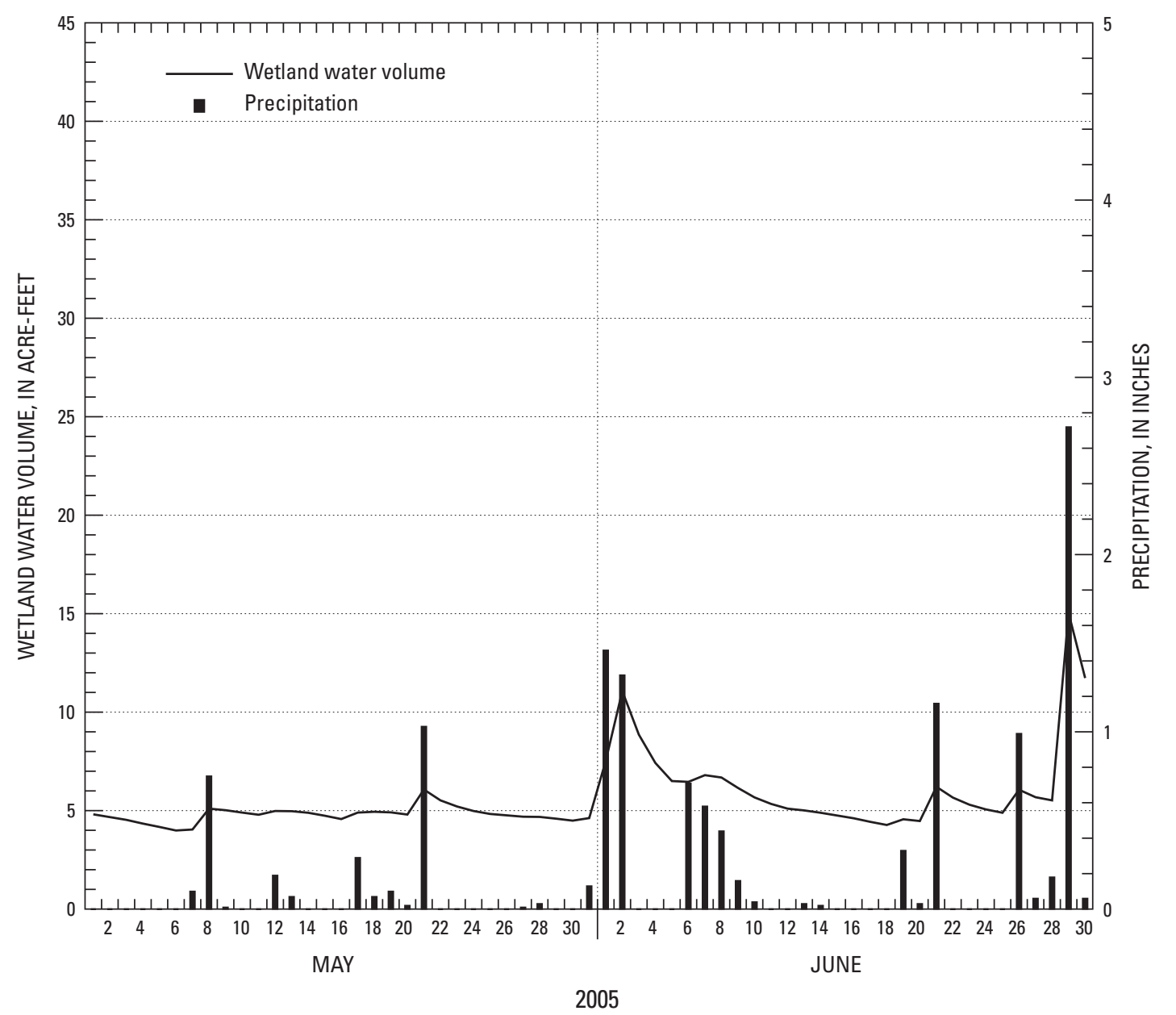

Figure 4. Simulated daily wetland water volumes and daily precipitation using the historical climate data set for May and June 2005 in the wetland water-balance model.

The historical-enhanced simulation indicated greater wetland water volumes and greater culvert flow than the historical simulation (table 2). Wetland water volumes remained greater than 5 acre-feet and flow occurred from the outlet culvert during the entire historical-enhanced simulation. The maximum simulated wetland water volume was about 16.2 acre-feet; the maximum occurred on June 29 as a result of a 2.72-inch rainfall (table 2; fig. 5). The simulated water-surface elevation in the study wetland on June 29 was about 2,067.06 feet, or, water would have been about 1.2 feet deep at the outlet culvert. The maximum simulated area contributing to runoff on June 29 was about 64.4 acres, and the maximum simulated culvert flow was about 5.6 acre-feet per day. Simulated culvert flow was greater than zero on every day during the simulation.

The extreme summer simulation indicated the maximum wetland water volume was about 38.6 acre-feet; the maximum occurred on June 24 after 2 days of artificially enhanced rainfall (table 3; fig. 6). The simulated water-surface elevation in the study wetland on June 24 was about 2,068.52 feet, or, water would have been about 2.6 feet deep at the outlet culvert. The maximum water-surface elevation from the extreme summer simulation was about 1.5 feet greater than the maximum water-level elevation from the historical-enhanced simulation. The maximum simulated area contributing to runoff on June 24 was about 122 acres, and the maximum simulated culvert flow on June 24 was about 16.8 acre-feet per day.

The extreme winter simulation indicated the maximum wetland water volume was about 132 acre-feet; the maximum occurred on April 30 (table 4; fig. 7). The simulated watersurface elevation in the study wetland on April 30 was about 2,072.04 feet, or, water would have been about 6.2 feet deep at the outlet culvert. The maximum simulated area contributing to runoff on April 24 was about 122 acres. Outlet-culvert 
flow was set to zero acre-foot per day to simulate the complete blockage of the culvert with snow and ice.

The minimum elevation of Highway 23 located directly north of the study wetland was 2,074 feet based on data from topographic maps. Therefore, at the greatest simulated water level on April 30, water was not likely to overflow the highway. The possibility exists at water-surface elevations above 2,068 feet that the topography of the land surrounding the study wetland may permit greater increases in water-surface area for increases in water-level elevation than indicated by equation 1 and also permit lesser increases in wetland watersurface elevation for increases in wetland water volume as determined by the water-balance model.

Model simulations indicate the study wetland would likely contain water during most historical and extreme climate events with the addition of maximum potential discharges of 0.6 acre-foot per day from proposed refinery holding ponds. The simulation performed using the extreme winter data set resulted in the greatest wetland water volume and water-surface elevation, but water was not likely to overflow an adjacent highway. Two additional simulations were performed using the historical and historical-enhanced climate data sets and the same initial conditions as the other simulations but with no precipitation during May and June 2005. The simulation using the historical climate data set with no precipitation indicated about 0.5 acre-foot of water remained in the wetland at the end of the simulation period (results not shown). The simulation using the historical-enhanced climate data set with a minimum potential discharge of 0.09 acrefoot per day from the holding ponds and with no precipitaton indicated about 3.8 acre-feet of water remained in the wetland at the end of the simulation period (results not shown). No culvert flow occurred during either simulation. Extended periods with little precipitation and above-normal temperatures may result in the wetland becoming dry, especially if potential holding-pond discharges are near zero.

Table 2. Daily precipitation and evapotranspiration data and selected simulation results from the historical-enhanced climate data set for May and June 2005.

\begin{tabular}{cccccccc}
\hline $\begin{array}{c}\text { Date } \\
\text { (month/day/vear) }\end{array}$ & $\begin{array}{c}\text { Precipitation } \\
\text { (inches) }\end{array}$ & $\begin{array}{c}\text { Evapotranspiration } \\
\text { (inches) }\end{array}$ & $\begin{array}{c}\text { Simulated area } \\
\text { contributing to } \\
\text { runoff } \\
\text { (acres) }\end{array}$ & $\begin{array}{c}\text { Simulated runoff } \\
\text { water volume } \\
\text { (acre-feet } \\
\text { per day) }\end{array}$ & $\begin{array}{c}\text { Simulated } \\
\text { culvert flow } \\
\text { (acre-feet } \\
\text { per day) }\end{array}$ & $\begin{array}{c}\text { Simulated } \\
\text { wetland } \\
\text { water volume } \\
\text { (acre-feet) }\end{array}$ & $\begin{array}{c}\text { Simulated } \\
\text { wetland } \\
\text { water-surface } \\
\text { elevation } \\
\text { (feet) }\end{array}$ \\
\hline $6 / 15 / 2005$ & 0 & 0.25 & 16.0 & 0 & 0.54 & 5.98 & $2,066.00$ \\
$6 / 16 / 2005$ & 0 & .25 & 16.0 & 0 & .51 & 5.92 & $2,065.99$ \\
$6 / 17 / 2005$ & 0 & .33 & 16.0 & 0 & .47 & 5.85 & $2,065.98$ \\
$6 / 18 / 2005$ & 0 & .31 & 16.0 & 0 & .45 & 5.81 & $2,065.97$ \\
$6 / 19 / 2005$ & .33 & .28 & 16.0 & .44 & .59 & 6.09 & $2,066.01$ \\
$6 / 20 / 2005$ & .03 & .26 & 16.0 & .04 & .56 & 6.02 & $2,066.00$ \\
$6 / 21 / 2005$ & 1.16 & .29 & 26.4 & 2.56 & 1.36 & 7.63 & $2,066.21$ \\
$6 / 22 / 2005$ & 0 & .29 & 25.8 & 0 & 1.04 & 6.99 & $2,066.13$ \\
$6 / 23 / 2005$ & 0 & .27 & 16.0 & 0 & .84 & 6.58 & $2,066.08$ \\
$6 / 24 / 2005$ & 0 & .27 & 16.0 & 0 & .70 & 6.31 & $2,066.04$ \\
$6 / 25 / 2005$ & 0 & .31 & 16.0 & 0 & .60 & 6.11 & $2,066.02$ \\
$6 / 26 / 2005$ & .99 & .12 & 22.0 & 1.82 & 1.18 & 7.27 & $2,066.17$ \\
$6 / 27 / 2005$ & .06 & .16 & 23.3 & .12 & .99 & 6.89 & $2,066.12$ \\
$6 / 28 / 2005$ & .18 & .15 & 16.0 & .24 & .91 & 6.72 & $2,066.10$ \\
$6 / 29 / 2005$ & 2.72 & .08 & 64.4 & 14.6 & 5.65 & 16.2 & $2,067.06$ \\
$6 / 30 / 2005$ & .06 & .20 & 61.8 & .31 & 4.00 & 12.9 & $2,066.77$ \\
\hline
\end{tabular}




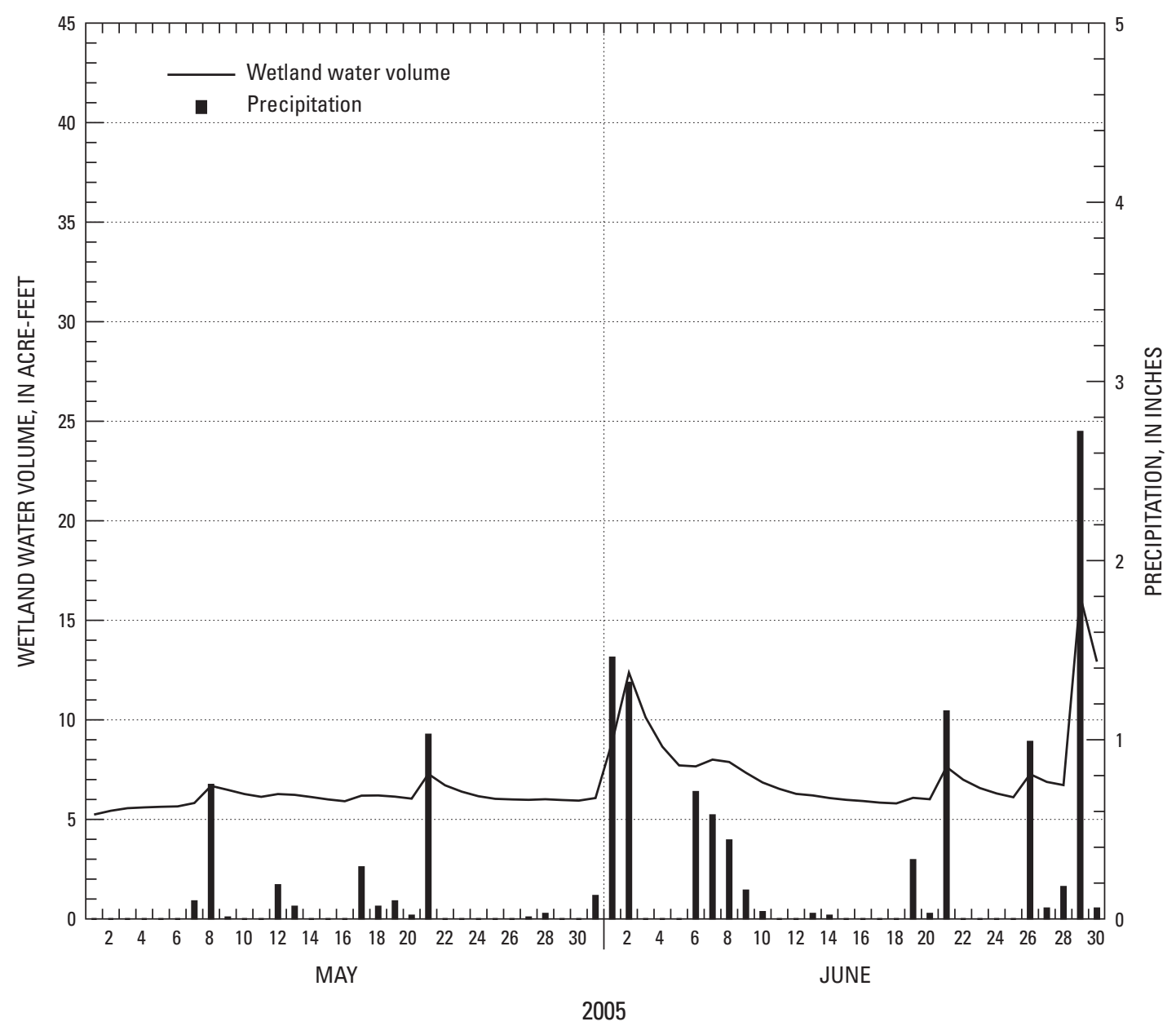

Figure 5. Simulated daily wetland water volumes and daily precipitation using the historical-enhanced climate data set for May and June 2005 in the wetland water-balance model.

\section{Model Limitations}

The wetland water-balance model was developed without water-level information or flow data from the study wetland and with little information about the potential for watershed runoff from precipitation events, so simulation results are considered preliminary. Although historical climate data were used to estimate extreme precipitation events, the possiblility exists that larger precipitation events could occur that would produce greater volumes of runoff to the wetland. Because the model could not be calibrated and validated, calculated wetland water volumes and water flows may not be representative of actual conditions at the study wetland. Errors in the calculation of potential wetland water volumes may have occurred as a result of errors in the elevations and locations of surveyed points, errors during contouring, and errors in the determination of potential water-surface areas. Plans for the proposed refinery were still being developed at the time of the study. Additional information regarding the size, position, and operation of the proposed holding ponds and possible alterations to the constructed ditch between the study wetland and adjacent wetland and lake would be useful for future model improvement.

\section{Summary}

To assist in the gathering of information for an environmental impact statement, the U.S. Geological Survey, in cooperation with the U.S. Environmental Protection Agency, developed a numerical water-balance model to simulate the responses of a wetland to historical and possible extreme hydrological inputs and to changes in hydrological inputs that might occur if a proposed refinery is built on the Fort Berthold 
Reservation, North Dakota. Surveys of the wetland were made to produce potential wetland water-surface area and water volume information for the model. Historical waterlevel and flow data from the study wetland were not available for model calibration and validation, so simulation results are considered preliminary.

The water-balance model was developed to determine wetland water volumes associated with historical climate events and with possible extreme precipitation events in conjunction with maximum potential discharges from the proposed refinery holding ponds. The daily water-balance model was developed with the following assumptions: (1) ground-water interaction with the study wetland was zero, (2) initial area contributing to runoff to the study wetland was 16 acres, (3) one-third of the wetland water volume above the outlet culvert entrance elevation flowed from the study wetland each day, (4) water flowed from the study wetland in the downstream (north) direction only, and (5) evapotranspiration from the calculated wetland open-water area occurred at the potential (Penman) rate.
Results from model simulations indicate that the study wetland would likely contain water during most historical and extreme-precipitation events with the addition of maximum potential discharges of 0.6 acre-foot per day from the proposed refinery holding ponds. The historical-enhanced simulation indicated that the maximum wetland water volume in the study wetland was about 16.2 acre-feet and the simulated water-level would have been about 1.2 feet at the outlet culvert. The extreme summer simulation indicated that the maximum wetland water volume was about 38.6 acre-feet and the simulated water-level would have been about 2.6 feet at the outlet culvert. The extreme winter simulation resulted in the greatest wetland water volume of about 132 acre-feet and the greatest water level, which would have been about 6.2 feet at the outlet culvert, but water was not likely to overflow an adjacent highway. Extended periods with little precipitation and above-normal temperatures may result in the wetland becoming nearly dry, especially if potential holding-pond discharges are near zero.

Table 3. Daily precipitation and evapotranspiration data and selected simulation results from the extreme summer climate data set for May and June 2005.

\begin{tabular}{cccccccc}
\hline $\begin{array}{c}\text { Date } \\
\text { (month/day/year) }\end{array}$ & $\begin{array}{c}\text { Precipitation } \\
\text { (inches) }\end{array}$ & $\begin{array}{c}\text { Evapotranspiration } \\
\text { (inches) }\end{array}$ & $\begin{array}{c}\text { Simulated area } \\
\text { contributing to } \\
\text { runoff } \\
\text { (acres) }\end{array}$ & $\begin{array}{c}\text { Simulated runoff } \\
\text { water volume } \\
\text { (acre-feet } \\
\text { per day) }\end{array}$ & $\begin{array}{c}\text { Simulated } \\
\text { culvert flow } \\
\text { (acre-feet } \\
\text { per day) }\end{array}$ & $\begin{array}{c}\text { Simulated } \\
\text { wetland } \\
\text { water volume } \\
\text { (acre-feet) }\end{array}$ & $\begin{array}{c}\text { Simulated } \\
\text { wetland } \\
\text { water-surface } \\
\text { elevation } \\
\text { (feet) }\end{array}$ \\
\hline $6 / 15 / 2005$ & 0 & 0.25 & 16.0 & 0 & 0.54 & 5.98 & $2,066.00$ \\
$6 / 16 / 2005$ & 0 & .25 & 16.0 & 0 & .51 & 5.92 & $2,065.99$ \\
$6 / 17 / 2005$ & 0 & .33 & 16.0 & 0 & .47 & 5.85 & $2,065.98$ \\
$6 / 18 / 2005$ & 0 & .31 & 16.0 & 0 & .45 & 5.81 & $2,065.97$ \\
$6 / 19 / 2005$ & .33 & .28 & 16.0 & .44 & .59 & 6.09 & $2,066.01$ \\
$6 / 20 / 2005$ & .03 & .26 & 16.0 & .04 & .56 & 6.02 & $2,066.00$ \\
$6 / 21 / 2005$ & 1.16 & .29 & 26.4 & 2.56 & 1.36 & 7.63 & $2,066.21$ \\
$6 / 22 / 2005$ & .50 & .24 & 36.9 & 1.54 & 1.57 & 8.04 & $2,066.26$ \\
$6 / 23 / 2005$ & 1.00 & .23 & 33.3 & 2.78 & 2.12 & 9.14 & $2,066.39$ \\
$6 / 24 / 2005$ & 4.50 & .17 & 122 & 45.8 & 16.8 & 38.6 & $2,068.52$ \\
$6 / 25 / 2005$ & .50 & .21 & 111 & 4.63 & 12.9 & 30.7 & $2,068.07$ \\
$6 / 26 / 2005$ & .99 & .12 & 33.1 & 2.73 & 9.63 & 24.2 & $2,067.66$ \\
$6 / 27 / 2005$ & .06 & .16 & 23.3 & .12 & 6.60 & 18.1 & $2,067.21$ \\
$6 / 28 / 2005$ & .18 & .15 & 16.0 & .24 & 4.63 & 14.2 & $2,066.88$ \\
$6 / 29 / 2005$ & 2.72 & .08 & 64.4 & 14.6 & 8.12 & 21.2 & $2,067.44$ \\
$6 / 30 / 2005$ & .06 & .20 & 61.8 & .31 & 5.64 & 16.2 & $2,067.06$ \\
\hline
\end{tabular}




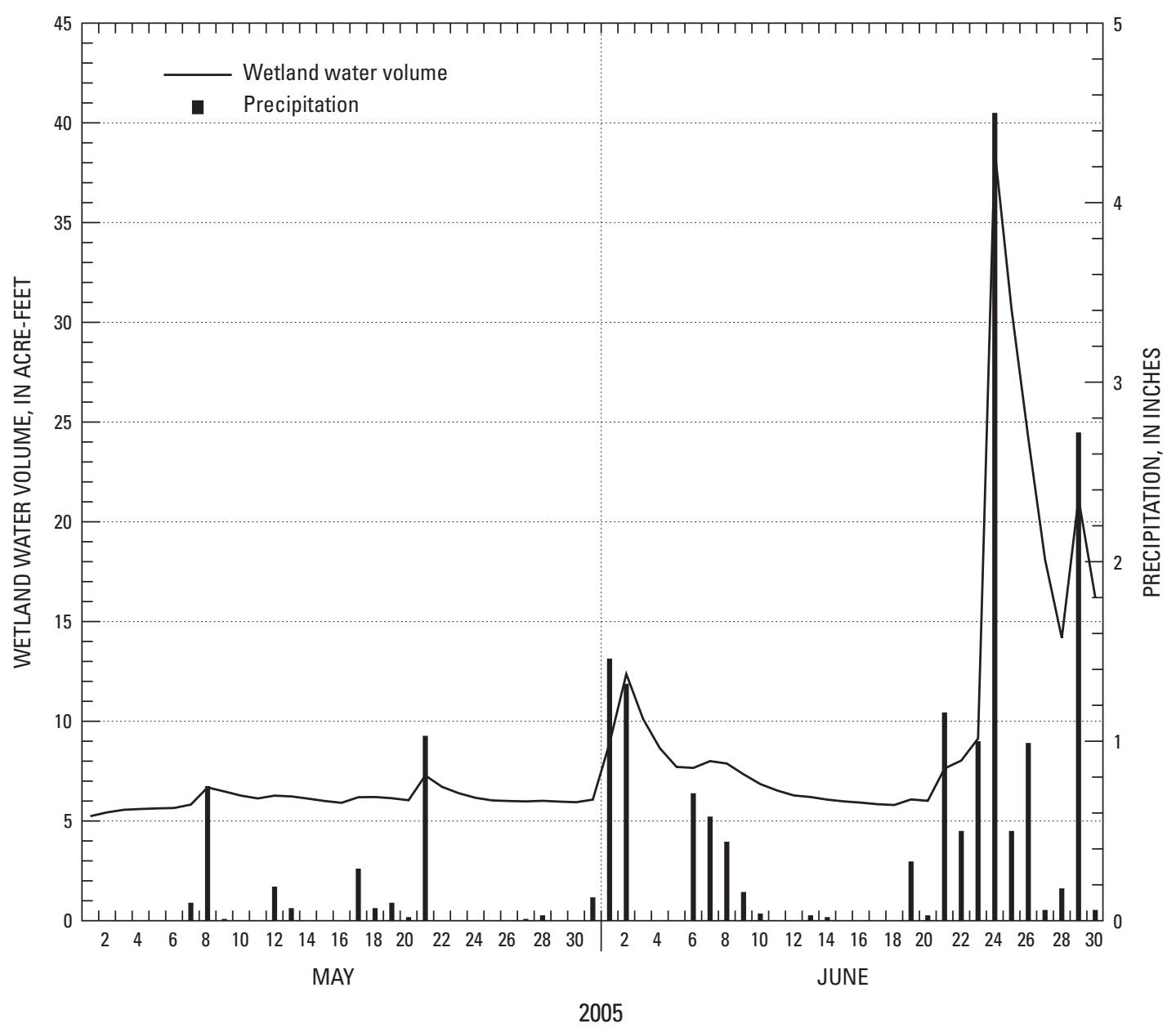

Figure 6. Simulated daily wetland water volumes and daily precipitation using the extreme summer climate data set for May and June 2005 in the wetland water-balance model. 
Table 4. Daily precipitation and evapotranspiration data and selected simulation results from the extreme winter climate data set for an arbitrary March and April.

\begin{tabular}{cccccccc}
\hline $\begin{array}{c}\text { Date } \\
\text { (month/day) }\end{array}$ & $\begin{array}{c}\text { Precipitation } \\
\text { (inches) }\end{array}$ & $\begin{array}{c}\text { Evapotranspiration } \\
\text { (inches) }\end{array}$ & $\begin{array}{c}\text { Simulated area } \\
\text { contributing to } \\
\text { runoff } \\
\text { (acres) }\end{array}$ & $\begin{array}{c}\text { Simulated runoff } \\
\text { water volume } \\
\text { (acre-feet } \\
\text { per day) }\end{array}$ & $\begin{array}{c}\text { Simulated } \\
\text { culvert flow } \\
\text { (acre-feet } \\
\text { per day) }\end{array}$ & $\begin{array}{c}\text { Simulated } \\
\text { wetland } \\
\text { water volume } \\
\text { (acre-feet) }\end{array}$ & $\begin{array}{c}\text { Simulated } \\
\text { wetland } \\
\text { water-surface } \\
\text { elevation } \\
\text { (feet) }\end{array}$ \\
\hline $4 / 15$ & 0 & 0.05 & 16.0 & 0 & 0 & 48.9 & $2,069.04$ \\
$4 / 16$ & 0 & .05 & 16.0 & 0 & 0 & 49.5 & $2,069.07$ \\
$4 / 17$ & 0 & .05 & 16.0 & 0 & 0 & 50.0 & $2,069.09$ \\
$4 / 18$ & 0 & .05 & 16.0 & 0 & 0 & 50.5 & $2,069.12$ \\
$4 / 19$ & .33 & .05 & 16.0 & .44 & 0 & 51.4 & $2,069.16$ \\
$4 / 20$ & .03 & .05 & 16.0 & .04 & 0 & 52.0 & $2,069.19$ \\
$4 / 21$ & 1.16 & .05 & 26.4 & 2.56 & 0 & 55.0 & $2,069.33$ \\
$4 / 22$ & .50 & .05 & 36.9 & 1.54 & 0 & 57.1 & $2,069.42$ \\
$4 / 23$ & 1.00 & .05 & 33.3 & 2.78 & 0 & 60.4 & $2,069.56$ \\
$4 / 24$ & 4.50 & .05 & 122 & 45.8 & 0 & 107 & $2,071.26$ \\
$4 / 25$ & .50 & .05 & 111 & 4.63 & 0 & 112 & $2,071.43$ \\
$4 / 26$ & .99 & .05 & 33.1 & 2.73 & 0 & 115 & $2,071.53$ \\
$4 / 27$ & .06 & .05 & 23.3 & .12 & 0 & 116 & $2,071.55$ \\
$4 / 28$ & .18 & .05 & 16.0 & .24 & 0 & 116 & $2,071.57$ \\
$4 / 29$ & 2.72 & .05 & 64.4 & 14.6 & 0 & 131 & $2,072.02$ \\
$4 / 30$ & .06 & .05 & 61.8 & .31 & 0 & 132 & $2,072.04$ \\
\hline
\end{tabular}




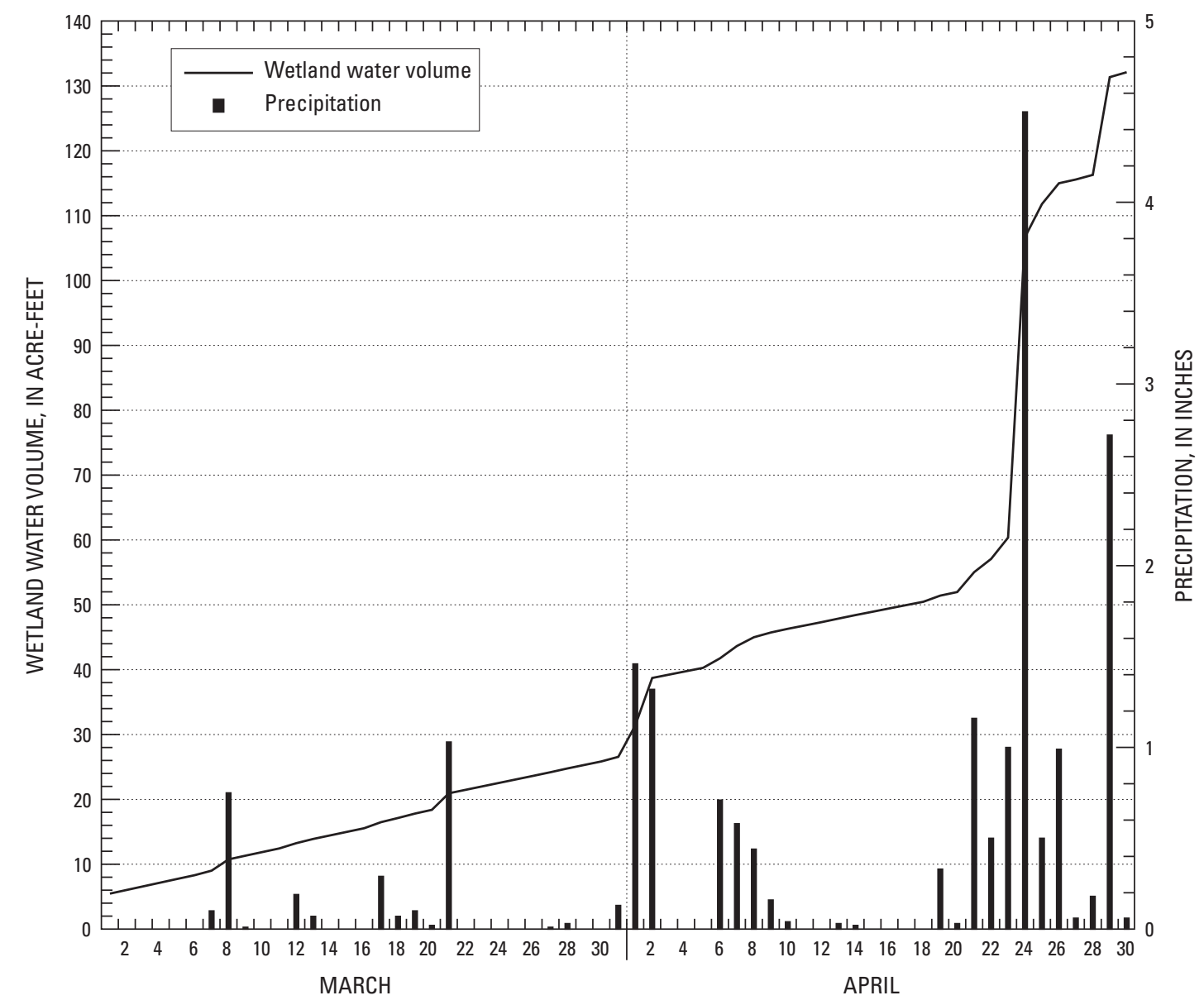

Figure 7. Simulated daily wetland water volumes and daily precipitation using the extreme winter climate data set for an arbitrary March and April in the wetland water-balance model. 


\section{References Cited}

Bodhaine, G.L., 1968, Measurement of peak discharge at culverts by indirect methods: U.S. Geological Survey Techniques of Water-Resources Investigations, book 3, chap. A3, $60 \mathrm{p}$.

High Plains Regional Climate Center, 2006, Climate Data: accessed June 2006 at http://www.hprcc.unl.edud.

Howey, R.L., Farris, C., Glatt, F., Hauff, F., Lahlum, S., Larson, S. Neubauer, L., and Wahl, F., 1974, Soil Survey of Ward County, North Dakota: U.S. Department of Agriculture, Soil Conservation Service, and North Dakota Agricultural Experiment Station, 92 p.

Johansen, M.P., Hakonson, T.E., and Breshears, D.D., 2001, Post-fire runoff and erosion from rainfall simulation - contrasting forests with shrublands and grasslands: Hydrological Processes, v. 15, p. 2953-2965.

Leavesley, G.H., Lichty, R.W., Troutman, B.M., and Saindon, L.G., 1983, Precipitation-runoff modeling system — User's manual: U.S. Geological Survey Water-Resources Investigations Report 83-4238, 207 p.

National Climatic Data Center, 2002, Monthly station normals of temperature, precipitation, and heating and cooling degree days 1971-2000, North Dakota: U.S. Department of Commerce, National Oceanic and Atmospheric Administration, Asheville, North Carolina, Climatography of the United States, No. 81, 32 p.

North Dakota State University, 2006, North Dakota Agricultural Weather Network: accessed June 2006 at http:// ndawn.ndsu.nodak.edu

Penman, H.L., 1948, Natural evapotranspiration from open water, bare soil and grass: Proceedings of the Royal Society of London, series A, Volume 193, p. 120-145.

Sorenson, J.R., 2004, The use of large plot rainfall simulation to investigate runoff generation on the Edwards Plateau, Texas: College Station, Texas A\&M University, master's thesis, $36 \mathrm{p}$.

U.S. Environmental Protection Agency, 2003, Notice of intent to prepare an environmental impact statement for the proposed Mandan, Hidatsa, and Arikara Nation clean fuels refinery, Ward County, ND: accessed June 2006 at http:/ www.epa.gov/fedrgstr/EPA-IMPACT/2003/November/Day07/i28119.htm

Woolhiser, D.A., and Brakensiek, D.L., 1982, Hydrologic system synthesis, in Haan, C.T., Johnson, H.P., and Brakensiek, D.L., eds., Hydrologic modeling of small watersheds: American Society of Agricultural Engineers Monograph No. 5, St. Joseph, Michigan, p. 3-16. 
Prepared by the Helena Publishing Service Center.

For more information concerning the research in this report, contact:

Director, U.S. Geological Survey

North Dakota Water Science Center

821 East Interstate Avenue

Bismarck, North Dakota 58503

(701) 250-7400

http://nd.water.usgs.gov/ 
